\title{
Two decades of programme-based promotion of workplace innovation in Finland: past experiences and future challenges
}

\section{Tuomo Alasoini}

\begin{abstract}
This article describes and explains the reasons for the rise and establishment of programme-based promotion of workplace innovation in Finland during the last 20 years. Several 'push' and 'pull' factors that have simultaneously promoted the consolidation of these efforts are presented. The author also examines the Finnish programmes and 'Nordic exceptionalism' in a broader European context, referring to the overall under-resourcing of workplace innovation activities in European public policies so far. At the end of the article, new challenges to workplace development deriving from the rapid reshaping of working life are discussed. Despite the rather gloomy picture that is painted of how debate on a good working life has been flagging in many European countries recently, the author believes that the significance of workplace innovations as one of the driving forces of the 'second wave' of ICT-based productivity growth will increase in the future. The author also welcomes the European Commission's new initiative, the EUWIN project, as an important indication that workplace innovations are also seen as increasingly important from the perspective of industrial policy in Europe.
\end{abstract}

Keywords: Development programme, Finland, new working life, quality of working life, workplace development, workplace innovation 


\section{Introduction}

In 2011, Prime Minister Katainen's government decided to draw up a National Working Life Development Strategy for Finland. The drafting of this strategy, which was prepared in cooperation with other ministries and the labour market partners, was led by the Ministry of Employment and the Economy. The strategy was completed in spring 2012 and its ambitious vision is that Finland will have the best working life in Europe in 2020 (Ministry of Employment and the Economy 2012). This vision has also attracted international interest, as the idea of 'a good working life' has in recent years hardly been a political objective of a high priority anywhere else in Europe.

The golden era of the debate on good working life in Europe stretched from the late 1960s till the late 1970s. As a political goal, the idea of a good working life was in its time given momentum by the efforts of progressive trade unions, employers and researchers to make working conditions more human, to increase workplace democracy and to develop ways of organising and managing labour that provided alternatives for Taylorist and Fordist doctrines. Key motives for renewing working life were the petering out of the productivity potential of mass production mentality, workers' dissatisfaction with their working conditions, and the difficulties experienced by employers in recruiting labour for fragmented industrial work.

While many programmes to reform working life were also implemented in various European countries after the work humanisation and workplace democratisation initiatives of the 1960s and 1970s, a good working life did not re-emerge in the same way as a political goal and a value in itself in Europe. The most active countries to implement such programmes include the Nordic countries, Germany and the Benelux countries. In these countries, too, the programmes have in recent years sought their justification, not in a good working life but in striving for economic growth through improved productivity and competitiveness of companies, and through promoting innovation activities and the introduction of new technologies (Alasoini 2009; Brödner and Latniak 2003; Eeckelaert et al. 2012; Totterdill et al. 2009). Improving the quality of working life (QWL) has either been considered less valuable and it has been overshadowed by other political goals, attitudes towards it have been reserved for ideological reasons, or finding shared goals for the activities among the conflicting views of various stakeholders including the labour market partners has proved impossible.

Finland has been an exception to this general trend. The humanisation initiatives only touched Finland lightly. Programme-based workplace development only began in Finland as late as in the 1990s, along with the launching of the National Productivity Programme and the National Workplace Development Programme. Since then, several programmes have been devised to develop Finnish working life. In recent years, these have been implemented by such actors as the Ministry of Labour, the Ministry of Social Affairs and Health, the Ministry of Education, the Finnish Institute of Occupational Health, State Treasury, the Finnish Funding Agency for Technology and Innovation (Tekes), European Social Fund and some employer and employee federations. However, the National Working Life Development Strategy represents the most powerful political will to renew working in Finland so far. 


\section{Objective and structure of the article}

This article has two objectives. The first one is to paint a picture of how programme-based promotion of workplace innovation has evolved in Finland, and what explains Finland's unique qualities in a European comparison. The article focuses on programmes implemented by the Ministry of Labour and Tekes. An important milestone for Finland is the year 2008, at which time the promotion of workplace innovation was incorporated in the concept of 'broad-based innovation policy'.

The second objective of this article is to evaluate the sustainability of the 'Finnish model for workplace development' in the current transformation of working life. The article probes the types of pressures to which the basic assumptions of this model appear to be exposed in the 2010s and asks how the actual workplace development activities should be developed in the future. Analyses of this type are scarce in the literature, excluding certain individual evaluation studies of completed programmes.

The Finnish experiences are of more general interest in Europe. Finland is one of the countries that in recent years has invested the most in working life renewal and the promotion of workplace innovations (see above). We can also say that Finland, similarly to the other Nordic countries, is among the forerunners of technological and organisational change in Europe (Beblavý et al. 2012; Eurofound 2012; Valeyre et al. 2009). There is a great need in Europe to enhance mutual programme and policy learning between countries in the area of promoting innovations in working life. Regardless of many joint European projects, some of which have been ambitions, mutual learning has so far remained modest. In the future, the three-year European Workplace Innovation Network (EUWIN) project launched in early 2013 and funded by the European Commission DG Enterprise and Industry, which for the first time aims to set up a co-operation network that covers the entire EU-27 area, will offer a new forum for mutual learning.

The article begins by discussing the history of programme-based promotion of workplace innovation in Finland. This discussion is divided into two chapters: the first one describes the rise, and the second one the establishment of these efforts. In the following chapter, the impact and significance of the Finnish programmes are assessed in the broader European context. The article then moves on to discuss the challenges to which the on-going working life change exposes the principles of 'the Finnish model for workplace development', and finishes with a summing up and conclusions.

\section{The rise of workplace development in Finland}

The work humanisation and workplace democratisation initiatives did not spark similar debate on QWL and the need to develop new forms of work organisation in Finland as it did in many other Western industrial countries. At least the following causes can be found for this (Alasoini 2004): in the 1970s, many Finnish industrial workers still had a rural background and thus also previous experience of heavy work in farming or forestry; paucity of industrial mass production with highly fragmented and fast-paced production line work of the kind that was the focus of worker dissatisfaction in many other countries; a technological bias characteristic of Finnish management methods combined with a minor role given to social and leadership skills in the 
training of engineers; low-trust employment relations in many big industrial companies that did nothing to encourage development co-operation between management and personnel; and the lack of a strong, sociologically oriented tradition of working life research which might have prompted general debate on workplace development. Neither did impulses for workplace development come from technology policy. A strong institutionalised interest that would have striven for the integration of technical, social and environmental objectives in the technology policy in the 1970s and 1980s was lacking in Finland (Loikkanen and Seppälä 1994).

Interest in QWL and publically supported experiments with new forms of work organisation started petering out in many European countries from the 1980s on. The reasons for this can be sought in such facts as increasing unemployment that alleviated the problems of recruiting labour, the weakening influence of trade unions, the strengthening of market liberalism and the increasing tendency to search for solutions to productivity and competitiveness problems in the rapid development of ICT. In Finland, on the other hand, programme-based promotion of workplace innovation only began in the early 1990s, and financial resources set aside for it have continued to increase until the 2010s. The increase in workplace development has been simultaneously promoted by several 'push' and 'pull' factors in Finland.

One such 'push' factor has been Finland's long tradition in both bipartite co-operation between various labour market organisations, and tripartite cooperation between labour market organisations and public authorities. In the aftermath of the recession of the early 1990s, central employer associations and trade unions were well prepared to expand their co-operation with public authorities into workplace development. Another contributing 'push' factor has been the upsurge, beginning in the early 1980s, in working life research and, specifically, the rise of action-oriented working life research in universities and research institutes. This was a result of improved research financing opportunities, as well as being due to the culmination of problems in job satisfaction, work ability and early retirement, as well as the emergence of new approaches. These new approaches included, for example, participatory action research, sociotechnical systems design, organisation development (OD), developmental work research, process management and strategic human resource management (Kauppinen and Lahtonen 1994; Ramstad and Alasoini 2006). A third 'push' factor worth mentioning has been the strong conviction, prevalent in Finland, that research, $R \& D$ and high education are key factors in a nation's competitiveness. From an early stage, Finland took a systematic approach to adopting a national innovation system as the framework for its science and technology policies (Miettinen 2002). However, it is only in the 2000s that the promotion of workplace innovation has become a generally recognised sector within mainstream innovation policy (see below).

There are also 'pull' factors underlying the rise of workplace development in Finland in the 1990s. The rise did not take place so much as an attempt to improve QWL than as a 'corrective measure' to improve Finnish companies' poor economic performance in the aftermath of the recession. There also was a drive to look for the explanation for companies' productivity and competitiveness problems in their outdated operating practices. This view was reinforced by tougher international competition ensuing from the collapse of the Soviet Union market perceived as 'easy' for Finnish companies, incompetent investments in new technologies in the pre-recession years, and the breakthrough of process management. Especially the principles of lean production, including the streamlining of processes, leaner and flatter organisation structures, team work and continuous improvement (e.g. Womack and Jones 1996), fell on 
fertile ground in Finland. Applying these principles did not require great investments in companies recovering from recession. The rational rhetoric of lean production also fits in well with the Finnish management culture, and its eclectic nature made possible the simultaneous promotion of goals that were important for the employees and trade unions as well

From the viewpoint of companies, the legitimisation of workplace development supported with public funding was promoted by the fact that, as a result of the globalisation of the economy and in the hope of saving on their costs, companies started focusing on their core competence. They cut back on expert resources that were not part of their core activities, which increased their interest in outside research, development and training cooperation. Management consultation thus experienced a period of rapid growth in Finland in the 1990s (Ainamo and Tienari 2002). The competence and willingness of universities and research institutions to work together with companies also increased, as indicated above.

The first actual national level workplace development programme in Finland was the National Productivity Programme that was launched in 1993 on the initiative of labour market organisations. In 1996, the National Productivity Programme was complemented by the National Workplace Development Programme TYKE launched by the Prime Minister Lipponen's first government. TYKE was initially set up for a four-year period, but in Prime Minister Lipponen's second government programme, it was extended by another four years. TYKE and the National Productivity Programme were implemented in parallel until the end of 2003. Based on the programme of Prime Minister Lipponen's second government, the fouryear Well-Being at Work Programme was also launched in 2000. The Ministry of Labour was responsible for the practical implementation of all three programmes together with the labour market partners as well as some other ministries and providers of research funding. The set of programmes launched in the early 2000s also includes the National Programme for Ageing Workers (1998-2002) which, however, was more of a campaign in its nature than the programmes cited earlier, as well as certain European Social Fund programmes, which to some extent also included workplace development.

To continue the work of the TYKE programme and the National Productivity Programme, the Ministry of Labour launched the new Workplace Development Programme TYKES in 2004. TYKES concluded at the end of 2010. In March 2008, the implementation of this programme was transferred to Tekes. In 1996-2010, more than 1,800 projects were funded through the TYKE and TYKES programmes, and some EUR 106 million of public funding was allocated to them. A clear majority of the projects (more than 1,500) consisted of development projects started with initiatives made by workplaces. Typical targets of the projects included work processes, organisation of work, supervisory tasks, work community, working methods and business-to-business networks. The objective of the projects was to improve the productivity of work and QWL at workplaces simultaneously. Nearly 350,000 people took part in the projects at workplaces. In practice, projects were implemented in all sectors and at workplaces of all sizes nationwide. Other national programmes in early 2000s that included working life development in Finland were the Veto Programme coordinated by the Ministry of Social Affairs and Health (2003-2007), which mainly was follow-up for the National Programme for Ageing Workers and the Well-being at Work programme, the KESTO programme coordinated by the Finnish Institute of Occupational Health (2004-2007) and the Ministry of Education's Noste 
Programme (2003-2009). The European Social Fund also continued to fund workplace development through some of its programmes.

Implementation of the TYKE and TYKES programmes was guided by a set of principles which together can be, in retrospect, characterized as 'the Finnish model for workplace development'. It can be deemed justifiable to speak of such a 'model' at least in the sense that several ministries, labour market partners as well as a number of other funding bodies for working life research and workplace development were represented in the programmes. The main principles of the model can be summarised as follows (Alasoini 2012):

- System-level approach: The target of development at the workplace level should be a work system that consists of several interrelated work, organisational and human resource management practices on the whole, rather than individual practices as such.

- Productivity and QWL: A mutually supporting relationship between the promotion of productivity and QWL at workplace level is possible, i.e. both can be supported with similar kinds of development methods. Productivity growth achieved in this way can be called sustainable.

- Local learning processes: Workplace innovations usually call for a great deal of 'local reinvention', which means that with a view to promoting sustainable productivity growth it is more important to support local learning processes rather than transfer ready-made 'best practices' from one workplace context to another.

- Labour-management co-operation: Co-operation between management and personnel in development is important, because in this way it is possible to utilise versatile expertise in the planning and implementation of new solutions, and to create shared understanding and acceptance based on the decisions that will be made.

- Research-supported development: Interplay between research and development in projects often provides more favourable conditions both for innovative workplace-level solutions and the creation of new generalised knowledge than research or development alone.

- Expanded triple helix (on the concept, see Ramstad 2008): In modern knowledge-based societies, there usually are several clusters of innovation which possess different kinds of knowledge, implying that the most favourable conditions for workplace innovations derive from close interaction and co-operation between them.

- Inclusiveness: For the maintenance of the conditions for the Finnish welfare state, it is important to foster innovative development in many sectors of the economy and in many kinds of workplaces rather than focus on leading-edge sectors and workplaces alone. 


\section{Establishing the position of workplace development in the context of new innovation policy}

In 2007, Prime Minister Vanhanen's second government made a decision to establish the Ministry of Employment and the Economy. In the aftermath of this reorganisation, the TYKES programme was transferred from the Ministry of Labour to Tekes, the biggest innovation funding agency in Finland, and improving QWL was made part of the statutory duties of Tekes. In addition to the reorganisation of the ministries, establishing the position of the promotion of workplace innovation, and transforming it from a programme-based activity into a permanent operation of Tekes was also associated with the adoption of a new national innovation strategy.

The Government assigned in 2007 the Ministry of Trade and Industry to appoint a high-level group with the task of drawing up a proposal for a new national innovation strategy. The group, chaired by former Prime Minister Aho, submitted a proposal for a new kind of 'broad-based innovation policy' (Aho et al. 2008). The central idea of the proposal involved further expanding the target of innovation policy to give more significance to non-technological innovations and increasing the positive joint impacts of technological and non-technological innovations. The proposal also placed greater emphasis on the role of customers, users, ordinary employees and communities of different kinds in innovation. The Government approved the central recommendations of the strategy proposal in October 2008.

However, some international experts have suggested that Finland has not progressed very far in applying its new innovation thinking. For example, an international evaluation of the Finnish innovation system considers the content of the new broad-based innovation policy to still be fuzzy, vague and potentially even 'too broad' (Veugelers et al. 2009). There was also relatively little debate on what the linking of workplace development with the new concept of innovation policy would mean for the target or the content of workplace development, in connection with either drafting the legislative amendments or the preparation of the innovation strategy.

The National Working Life Development Strategy, which was drafted under the leadership of the Ministry of Employment and the Economy, was adopted in spring 2012. This strategy is inclusive and work organisation centred as it highlights the fact that development should begin within individual work organisations and that all work organisations should develop from their own starting points. Instead of dealing with only certain types of work organisations, the strategy describes paths for work organisations that are on 'good basic level' to move to the level of 'developer', and paths for work organisations that are on the level of 'developer' to become 'forerunners'. The four focus areas on which development should be supported in the strategy are innovation and productivity, trust and co-operation, health and well-being at work, and skills and competencies of the workforce (Ministry of Employment and the Economy 2012).

As part of the strategy, Tekes launched in August 2012 a new programme, entitled 'Liideri Business, Productivity and Joy at Work'. Liideri is a programme for the development of business, in which companies renew their operations through developing management and forms of working and actively utilising the skills and competencies of their personnel. On the one hand, Liideri is a follow-up programme to the TYKE and TYKES programmes. On the other hand, the purpose of Liideri is to be a 'next-generation' workplace development programme that represents an approach in keeping with a broad-based innovation policy 
(Alasoini 2012). At the project level, this means, first and foremost, an interconnecting link between traditional objectives and targets in the development of working life, such as work productivity, quality of working life and well-being at work, and a link between them and corresponding objectives and targets in the development of products, services and business operations.

The Liideri programme has three focus areas. The first of them is management 2.0. This concept refers to management principles, processes and practices, which help an organisation to promote the initiative, creativity and innovation potential of personnel, with a view to achieving competitive edge based on them. The main focus in Liideri projects is on the level of management processes, i.e. entities of interconnected practices that apply to management and help the organisation reach its objectives (cf. Birkinshaw 2010). A special emphasis is laid on processes of innovation management, knowledge management, diversity management, strategic human resource management and value management.

The second focus area concerns employee-driven innovation (EDI). EDI refers here to active and systematic participation of employees in ideation, innovating and renewing of products and services and ways of producing them, with a view to creating new solutions that add value to customers (cf. Høyrup 2012). Within this generic definition, EDI processes on three different levels are identified in Liideri. In its least institutionalised form, EDI refers to self-organised (continuous) remaking of jobs and activities. Employees plan and implement solutions that help them solve work-related challenges and problems in a creative manner that is productive for the entire organisation (first order EDI). The second level is (fully) employee-driven innovation that produces solutions that arise from employees' self-initiated ideation and are both recognised and acknowledged by the management (second order EDI). The most institutionalised level is employee-involving innovation. This refers to solutions based on commissions by management, customers or various stakeholders in which the employees have actively participated (third order EDI).

The third focus area concerns new ways of working. This concept refers to work, which transcends the boundaries of time-honoured temporal, spatial and organisational patterns and forms of work, or which in some other recognised way embody principles of management 2.0. New ways of working that are based on these general principles can be very different. Common to all of them, in particular, is the fact that management becomes a more shared activity and that work is done in a more individual ways and is more decentralised in terms of being done in different locations, at different times and with changing groups of people in different networks. Another important precondition for dissemination of new forms of working is the continuous development of ICT-based applications. This creates new opportunities for digitalisation of data reserves, continued reduction of the cost of data and information processing, and increasing connectivity of and speed of access to various types of data and information.

The primary target group in the Liideri programme consists of small and medium-sized enterprises, which pursue growth from the innovation-derived competitive edge of their business activities, utilising and developing preconditions for active and systematic participation of their personnel in innovation and other development activities. Other kinds of companies and public organisations can also receive funding for projects that show high innovative value and can act as important sources of ideation and inspiration for other 
organisations. The projects should aim at extensive renewal of their ways of operation, build on extensive networking and also permit other organisations to have access to the key results of their projects. Consultants and (action) researchers work in projects supporting companies, just as in the TYKE and TYKES programmes.

The aim is to get at least 300 companies or other organisations to launch programme-funded projects, of which at least $70 \%$ should bring about clear and measurable improvements in productivity and well-being at work. In addition, the aim is for at least 1,000 companies or other organisations to make use of the programme services or gain concrete benefits from the programme for running their own business or other activities.

\section{Finnish programmes in a broader context: their position and significance}

Even this short review suffices to show that Finnish working life has been the object of active development in recent years. The difference to other Nordic countries, in which working life has also seen active development efforts in recent years, is that in Finland, the Government has had a stronger input in influencing workplace level changes through various programmes and projects (Gustavsen 2007). In European level comparisons, the remarkable feature is a clear division between the more active north and the more passive south, and the scarcity or complete absence of development actions in the main part of the so-called new member states of the European Union (Eeckelaert et al. 2012).

A high QWL is not only a luxury product that can be achieved as a manifestation of favourable economic growth or generous welfare policy. It is also a considerable potential source of competitive advantage in an increasingly global economy. Company and establishment level data from such countries as Denmark (Laursen and Foss 2003; Nielsen and Lundvall 2007; Nielsen et al. 2012), the Netherlands (Beugelsdijk 2008), Great Britain (Shipton et al. 2005) and the United States (Messersmith and Guthrie 2010) show that advanced management and organisational practices and the good possibilities of learning and exerting influence at work engendered by them have a positive correlation with companies' ability to come up with product and service innovations. Producing innovations, on the other hand, is an extensive organisational learning process at best that also promotes opportunities for developing their work, and in their work, for those taking part in it. According to contingency thinking (e.g. Schuler and Jackson 1987), shortcomings in the ability to innovate, on the other hand, can impel companies to look for competitive advantage purely from costs, which can further have negative impacts on the possibilities of developing QWL. This can result in a self-perpetuating vicious circle.

Arundel et al. (2006), for example, have stated that the bottleneck in improving the innovative capabilities of European firms might not lie in the low levels of R\&D expenditure, which are strongly determined by industry structures and therefore difficult to change, but in the widespread existence of work contexts that are unable to provide a fertile environment for innovation. According to them, 'If this is the case, then the next step for European policy is to encourage the adoption of 'pro-innovation' organisational practice, particularly in countries with poor innovative performance' (ibid.: 29). Their views are based on analyses that draw on Eurofound Working Conditions Surveys. 
The position of the Nordic countries as forerunners of QWL and its development has often been explained through various regime or system theories (e.g. Dobbin and Boychuk 1999; Gallie 2007; Oinas et al. 2012). These theories are based on views according to which organisational forms that differ from each other in a relatively permanent and systemic manner can be found between capitalist economies. The explanations offered by regime or system theories remain flimsy, however, in the sense that they operate with very rough classifications and look for explanations by referring to regimes or systems that are static, or 'given'. It is obvious, however, that the position of the Nordic countries as forerunners of organisational changes has been promoted by special features of Nordic capitalism in a wider sense than what these explanation models indicate. In particular, such features include advanced technologies, a high educational level of the labour force, co-operative labour and employment relations, openness of the economy and a high dependency on exports. The special features of Nordic capitalism are also linked with the idea of an enabling welfare state, the specific institutional forms of which, however, have wide differences between individual countries. Thus, its most essential feature is not institutional forms of a certain type but an institutional experimental nature, which also applies to the ways work is organised (Kristensen and Lilja 2011; Kristensen and Morgan 2012).

The idea of an enabling welfare state can also be linked to a rapid change of working life and a high QWL life through two similes (Figure 1). Firstly, the enabling welfare state has offered people safety nets by evening out the risks in working life changes. It has also served as a springboard by being a key force that in itself mobilises people and work organisations to reform. This mobilisation process has in particular taken place through investments in competence, learning and creativity in particular, but also through investments that target participation in working life and increase consumption in more general terms. 


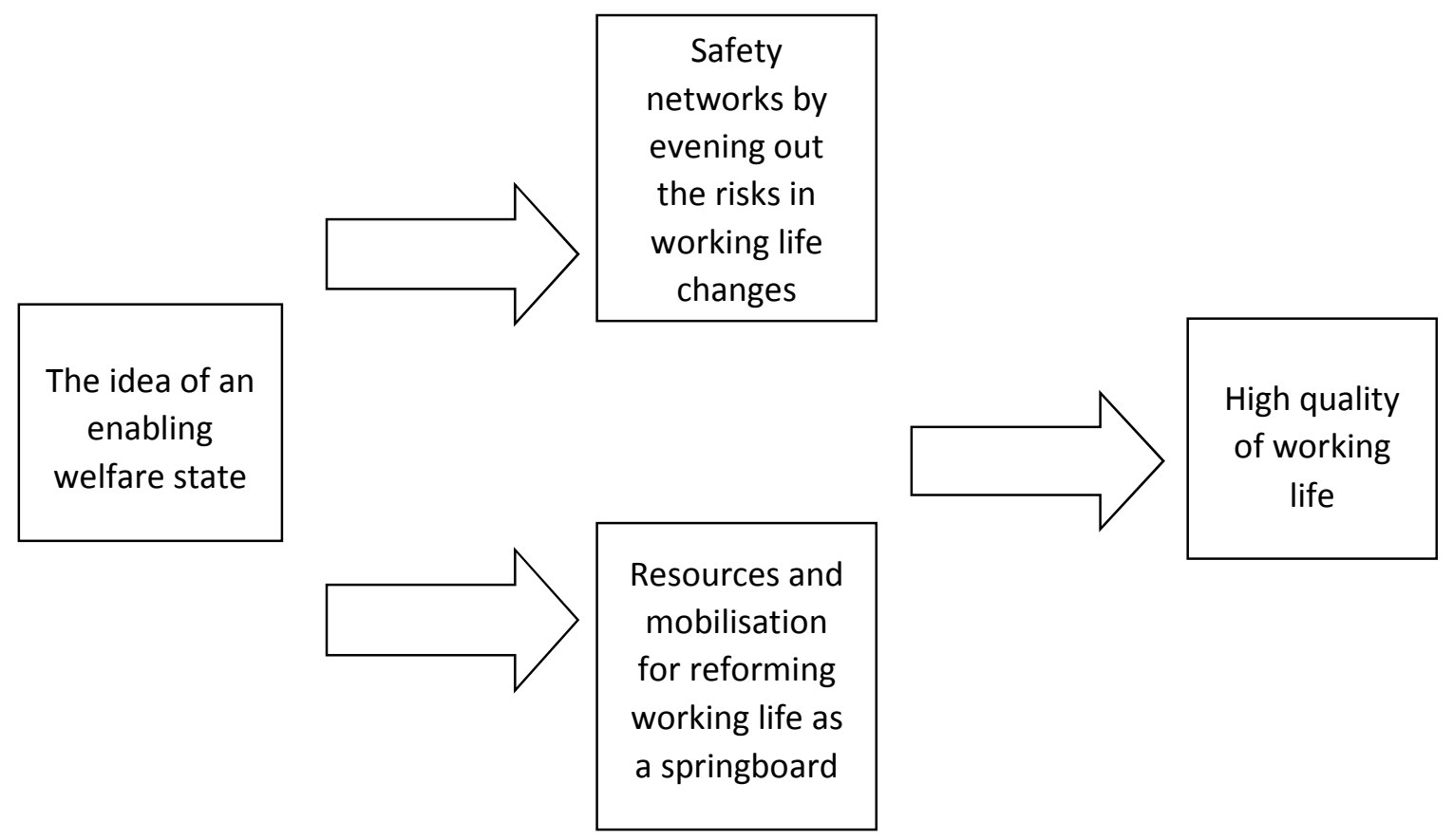

Figur 1 The idea of an enabling welfare state and high quality of working life.

Megatrends, such as the globalisation and networking of the economy and the development of ICT, percolate through different institutional structures in different ways, depending on the country in question. The new management doctrines concerning such megatrends do not therefore have a mechanical influence but instead take on hybrid forms at national level on the basis of local (re)interpretations. As a good example of such "hybrid forms" can be mentioned Nordic lean production model applications, which differ in many ways from their typical Japanese and Anglo-American counterparts, for instance (e.g. Lotz and Kristensen 2012; Oudhuis and Tengblad 2013; Seppälä and Klemola 2004). Oinas et al. (2012) showed, drawing on Eurofound working conditions studies, that Denmark, Finland and Sweden have retained their advantageous position concerning job quality compared with other EU countries between 1995 and 2010 in the era of globalisation and rapid technological change. Such national institutional structures, which in Finland and in the other Nordic countries have had a positive influence on QWL so far, are, however, also subject to changes themselves. The positive effect of these systems in the future is not a foregone conclusion but will require their constant development in the form of institutional experimentalism on the basis of a common understanding among the parties concerned.

Unavoidably, workplace development programmes alone are powerless to have a groundbreaking impact on the progress of working life change in themselves. These programmes mainly offer us a possibility of striving to strengthen desirable trends or to prevent undesirable ones. A precondition for this is that the activities are based on a visionary assumption of the current trends and the threats and possibilities inherent in these, and an ability to implement these promotive/preventive measures. The arguments used to legitimise the promotion of workplace innovations through various programmes are in principle the same as those for any intervention to promote innovations in general. Above all, these arguments include deficiencies of the market mechanism, system failures of existing institutions as well as the various positive externalities of interventions and innovations (cf. Edquist et al. 2001; Veugelers et al. 2009). 
The impacts and effectiveness of Finnish programmes (TYKE and TYKES) can, based on evaluation studies (Arnkil 2008; Arnkil et al. 2003; Oosi et al. 2010) be described as follows: As their most visible impacts can be seen immediate improvements in the productivity and effectiveness of work and various factors of QWL at participating workplaces. Many of the most successful workplaces have been small or medium industrial companies. As the second most important impact, the evaluation studies highlight the strengthening of working life research and development of infrastructure, including the number and competence of experts specialising in this area at universities and research institutes, and the networking between such experts. As the third most important impact can be cited boosting public debate on and awareness of the economic and other societal significance of the promotion of workplace innovation in Finland.

Evaluation studies indicate that there are two areas which can be considered the most problematic. Alasoini (2008) calls these the second-order and generative results of the projects. Second-order results from projects demonstrate how durable the improvements attained are and whether they are supported by changes which promote the development capability and learning capacity of those work organisations participating in the project. Generative results show how results from projects supported through the programme benefit other parties besides those directly involved in the project. The problem with regard to generative results is that they do not necessarily, and in workplace development not even primarily, involve ready-made 'best practices' that can then be transposed from one context to another; rather they involve the production and dissemination of interesting ideas which can become sources of inspiration or encouragement to actors outside the project. Regardless of many attempts and even innovative experiments, including interactive events or support for learning networks, the TYKE and TYKES programmes to a great extent failed to deliver on their ambitious goals, especially as regards generative results (Alasoini et al. 2011).

\section{Workplace development in the 'new working life'}

Technological advancement, globalisation of the economy, actualisation of environmental issues as well as demographic, social and cultural changes will in the next few years shape working life in many ways. For example, networking of the economy, distribution of work and management, expanding possibilities of the interactive Internet and social media, the entry of the net generation into working life and the individualisation of work orientations will put a question mark on many ideas of work and its organisation inherited from the industrial era (e.g. Gratton 2011; Meister and Willyerd 2010). The reshaping of working life will also be a significant challenge to many time-honoured methods of developing working life.

Working life will not change in a deterministic, straightforward or smooth manner. The features of the new working life will manifest themselves differently in different sectors, industries, organisations and tasks. Rather than completely displacing the old ones, they will be deposited as new historical layers upon the old ones. Gratton (2011: 11) notes that while the working life of the future is already here, it is unevenly distributed. In other words, practices, models and logics of the new working life can already be found today in multiple guises in the various phenomena of our time. 
However, speculations about working life that reach into the future have hardly been extended into the area of workplace development. Debate on the pressures that the trends of working life change we are able to anticipate will put on the basic assumptions and methods of workplace development is so far scarce. In the following, three of these challenges are discussed, reflecting on the principles of 'the Finnish model for workplace development' (see above).

The principles of this model included seeing the workplace at the core of the development efforts and targeting development on a work system that consists of several interrelated work, organisational and human resource management practices. The definition of what such terms as a 'workplace' will mean in the future may, however, become more vague than before, especially in situations where the work is virtual, mobile and distributed, services are produced in various types of networks, development takes place in projects with variable consistencies and different organisations, or staff serving a number of different employers work at the same physical workplace. We could well ask if an individual company with a more or less hierarchical organisation (or a 'workplace' in the conventional sense of the concept) any longer is the most fruitful environment for innovations in working life. Or will loose, reflexive communities and networks capable of flexible adaptation more and more frequently be at the core of innovative development in the future?

Another important topic for consideration is what QWL will mean in a situation where work becomes more knowledge and service intensive, people's work orientations are more individualistic, and changes at workplaces are more frequent. In the future, it will be increasingly difficult to set generally applicable, concrete criteria that lend themselves to objective measurement for a good QWL. On one hand, this is because in knowledge and service intensive work, a good work performance typically requires a stronger mental commitment than in traditional manual work. The possibility of becoming committed and thus achieving experiences of success in this type of work is also a key factor in producing subjective wellbeing. The preconditions for this are to a great extent determined by individual situations and dependent on the personal work orientation of each employee. The commitment is promoted by the employee's opportunities for a sense of coherence, or an ability to control the work and to find in it features that are comprehensible and meaningful (Antonovsky 1987; Kira 2002). On the other hand, in environments where change is more or less continuous, it will be increasingly difficult to try and develop QWL primarily through certain structural features of work that unavoidably will be short in duration. The question of the employee's possibilities of exerting influence and feeling inclusiveness in the context of changes that concern her/him will emerge as an increasingly important precondition for a good QWL (Alasoini 2012).

The third topic for consideration is relevant to the question of co-operation between management and staff and their roles in the development efforts. Traditional roles will become partly confused in the new working life. The dualism of management and staff, which has in particular directed development driven by the tradition of industrial relations, will partly disappear and be reshaped when exposed to ways of working that are increasingly networkbased, project-like and communal, or based on shared management and self-management. In organisations, which compete with flexibility, customer-orientation and agility, managing, supervising and organising work will no longer be tasks that only belong to people in managerial and supervisory positions, nor will they be limited to a single organisation any longer. More and more of the responsibility for these tasks will be shifted to non-managerial 
employees and to the teams and communities formed by them. As self-management becomes more common, many traditional forms of representative participation will unavoidably seem rather slow, and many traditional forms of direct participation will appear rather a weak means of exerting influence in the eyes of the employees. Along with them, new forms of participation, co-operation and partnership will be needed.

\section{Summary and conclusions}

This article gives a review of the 20-year history of programme-based promotion of workplace innovation in Finland, examines the unique quality of Finland in a European comparison in this field, and discusses the challenges that the on-going working life change is setting to our customary ways of workplace development. Workplace development started later in Finland than in many European countries and in the other Nordic countries in particular. The special feature in Finland is that in recent years, the Government has shown a strong commitment to the promotion of workplace innovation through various programmes. The strongest political expression of this was the National Working Life Development Strategy completed in 2012, as part of which the Liideri programme was launched by Tekes. The integration of the promotion of workplace innovation as part of the extended concept of innovation policy has also probably been taken further in Finland than in any other European country.

While the article paints rather a gloomy picture of how debate on a good working life has been flagging, or even non-existent, in many European countries recently, there are also signs of change in the air. The EUWIN project (2013-2015), funded by the European Commission, is an important indication of the fact that workplace innovations are also seen to be important from the perspective of industrial policy in Europe. It has also been suggested that while the 'first wave of productivity' based on the breakthrough of ICT in the 1990s had its roots in the application of new technologies to products, services and process streamlining, in the future productivity growth is more likely to be driven by organisational and institutional innovations that exploit new technologies. As the driving forces of the 'second wave' of ICT-based productivity growth have been seen factors associated with organisations' ability to collaborate, their collaborative relationships and culture, or in other words, various business management, workplace and other social innovations (Gratton 2011; Heckscher 2007; Perez 2002).

Workplace development programmes' capacity to promote innovations of this type during the 'second wave of productivity' will depend on their ability to reinvent themselves, enabling them to respond to challenges that will emerge during the transformation that is under way. Some of the key questions are to what extent the individual company/workplace remains the main target for development, what QWL means, how the roles of management and staff will become mixed and reshaped in self-managing work systems and what forms of participation, co-operation and partnership will be needed in the new working life. In various times of turbulence (as we are now), the possibility of having access to new information and visions, exchanging experiences and learning from solutions made by others will become increasingly important. From this perspective, various European and other international forums may in the future play an increasingly important role in how well workplace development programmes will maintain their societal relevance and impact, both at the national and the regional level. 


\section{References}

Aho E., Brunila A., Eriksson J.-T., Harjunen P., Heikinheimo R., Karjalainen S., Kekkonen T., Neittaanmäki P., Ormala E., Peltonen P., Pöysti K., Strengell M., Stenros A. and Teperi J. (2008) Proposal for Finland's National Innovation Strategy. Helsinki: Ministry of Employment and the Economy.

Ainamo A. and Tienari J. (2002) The Rise and Fall of a Local Version of Management Consulting in Finland. In Kipping L. and Engwall M. (eds.) Management Consulting: Emergence and Dynamics of a Knowledge Industry. Oxford: Oxford University Press, 70-90.

Alasoini T. (2004) The New Finnish Workplace Development Program (TYKES-FWDP) as an Approach to Innovation. Concepts and Transformation 9 (3), 279-295.

Alasoini T. (2008) Building Better Programmes: Learning Networks in the Promotion of Workplace Innovation. International Journal of Action Research 4 (1+2), 62-89.

Alasoini T. (2009) Strategies to Promote Workplace Innovation: A Comparative Analysis of Nine National and Regional Approaches. Economic and Industrial Democracy 30 (4), 614-642.

Alasoini T. (2012) A New Model for Workplace Development in Finland: Rethinking Employee Participation and the Quality of Working Life in the Context of Broad-Based Innovation Policy. International Journal of Action Research 8 (3), 245-265.

Alasoini T., Lahtonen M., Rouhiainen N., Sweins C., Hulkko-Nyman K. and Spangar T. (eds.) (2011) Linking Theory and Practice: Learning Networks at the Service of Workplace Innovation. TYKES Reports 75. Helsinki: Tekes.

Antonovsky A. (1987) Unraveling the Mystery of Health - How People Manage Stress and Stay Well. San Francisco: Jossey-Bass.

Arnkil R. (2008) In Search of Missing Links in Disseminating Good Practice - Experiences of a Work Reform Programme in Finland. International Journal of Action Research 4 (1+2), 39-61.

Arnkil R., Rissanen P., Pitkänen S., Piirainen T., Koski P., Berg,P., Vartiainen M., Gustavsen B., Ekman Philips M., Finne, H. and Riegler, C. (2003) The Finnish Workplace Development Programme: A Small Giant? Helsinki: Ministry of Labour.

Arundel A., Lorenz E., Lundvall B.-A. and Valeyre A. (2006) The Organisation of Work and Innovative Performance. DRUID Working Paper No. 06-14. Copenhagen: Danish Research Unit for Industrial Dynamics.

Beblavý M., Maselli I. and Martellucci E. (2012) Workplace Innovation and Technological Change. Brussels: Centre for European Policy Studies.

Beugelsdijk S. (2008) Strategic Human Resource Practices and Product Innovation. Organization Studies 29 (6), 821-847.

Birkinshaw J. (2010) Reinventing Management: Smarter Choices for Getting Work Done. San Francisco: JosseyBass.

Brödner P and Latniak E. (2003) Sources of Innovation and Competitiveness: National Programmes Supporting the Development of Work Organisation. Concepts and Transformation 8 (2), 179-211.

Dobbin F. and Boychuk T. (1999) National Employment Systems and Job Autonomy: Why Job Autonomy Is High in the Nordic Countries and Low in the United States, Canada, and Australia. Organization Studies 20 (2), 257291.

Edquist C., Hommen L. and McKelvey M. (2001) Innovation and Employment: Process versus Product Innovation. Cheltenham: Edward Elgar. 
Eeckelaert L., Dhondt S., Oeij P., Pot F., Nicolescu G.I., Trifu A. and Webster J. (2012) Review of Workplace Innovation and Its Relation with Occupational Safety and Health: Literature Review. Luxembourg: Publications Office of the European Union.

Eurofound (2012) Fifth Working Conditions Survey: Overview Report. Dublin: European Foundation for the Improvement of Living and Working Conditions.

Gallie D. (2007) Production Regimes, Employment Regimes, and the Quality of Work. In Gallie D. (ed.) Employment Regimes and the Quality of Work. Oxford: Oxford University Press, 1-33.

Gratton L. (2011) The Shift: The Future of Work Is Already Here. London: Collins.

Gustavsen B. (2007) Work Organization and the 'Scandinavian Model'. Economic and Industrial Democracy 28 (4), 650-671.

Heckscher C. (2007) The Collaborative Enterprise: Managing Speed and Complexity in Knowledge-Based Businesses. New Haven and London: Yale University Press.

Høyrup S. (2012) Employee-Driven Innovation: A New Phenomenon, Concept and Mode of Innovation. In Høyrup S., Bonnafous-Boucher M., Hasse C., Lotz, M. and Møller K. (eds.) Employee-Driven Innovation: A New Approach. Houndmills: Palgrave Macmillan, 3-33.

Kauppinen T. and Lahtonen M. (eds.) Action Research in Finland: Active Society with Action Research Conference, 25-27 August 1993, Helsinki, Finland. Labour Policy Studies 82. Helsinki: Ministry of Labour, 275302.

Kira M. (2002) Moving from Consuming to Regenerative Work. In Docherty P., Forslin J. and Shani,A.B. (eds.) Creating Sustainable Work Systems: Emerging Perspectives and Practice. London: Routledge, 29-39.

Kristensen P.H. and Lilja K. (eds.) (2011) Nordic Capitalisms and Globalization: New Forms of Economic Organization and Welfare Institutions. Oxford: Oxford University Press.

Kristensen P.H. and Morgan G. (2012) From Institutional Change to Experimentalist Institutions. Industrial Relations 51 (S1), 413-437.

Laursen K. and Foss N.J. (2003) New Human Resource Management Practices, Complementarities and the Impact on Innovation Performance. Cambridge Journal of Economics 27 (2), 243-263.

Loikkanen T. and Seppälä E.-O. (1994) Towards Social Orientation in Finnish Technology Policy. In Aichholzer G. and Schienstock G. (eds.) Technology Policy: Towards an Integration of Social and Ecological Concerns. Berlin: Walter de Gruyter, 323-347.

Lotz M. and Kristensen P.H. (2012) Moving Organizations towards Employee-Driven Innovation (EDI) in Work Practices and on a Global Scale: Possibilities and Challenges. In Høyrup S., Bonnafous-Boucher M., Hasse C., Lotz M. and Møller K. (eds.) Employee-Driven Innovation: A New Approach. Houndmills: Palgrave Macmillan, $167-184$.

Messersmith J.G. and Guthrie J.P. (2010) High Performance Work Systems in Emergent Organizations: Implications for Firm Performance. Human Resource Management 49 (2), 241-264.

Miettinen R. (2002) National Innovation Systems: Scientific Concept or Political Rhetoric. Helsinki: Edita.

Meister J.C. and Willyerd K. (2010) The 2020 Workplace: How Innovative Companies Attract, Develop, and Keep Tomorrow's Employees Today. New York: HarperCollins.

Ministry of Employment and the Economy (2012) National Working Life Development Strategy to 2020. Helsinki: Ministry of Employment and the Economy.

Nielsen P. and Lundvall B.-Å. (2007) Innovation, Learning Organisations and Industrial Relations. In Makó C., Moerel H., Illéssy M. and Csizmadia P. (eds.) Working It Out? The Labour Process and Employment Relations in the New Economy. Budapest: Akadémiai Kiadó, 65-83. 
Nielsen P., Nielsen R.N., Bamberger S.G., Stamhus J., Fonager K., Larsen A., Lund Vinding A., Ryom P. and Omland Ø. (2012) Capabilities for Innovation: The Nordic Model and Employee Participation. Nordic Journal of Working Life Studies 2 (4), 85-115.

(http://rossy.ruc.dk/ojs/index.php/njwls/article/view/2306/624, read 13 January 2013)

Oinas T., Anttila T., MustosmäkiA. and Nätti J. (2012) The Nordic Difference: Job Quality in Europe 1995-2010. Nordic Journal of Working Life Studies 2 (4), 135-152.

(http://rossy.ruc.dk/ojs/index.php/njwls/article/view/2520/827, read 13 January 2013)

Oosi O., Kotiranta A., Pekkala H., Wennberg M., Valtakari M., Karjalainen J. and Rajahonka M. (2010) Arjen muutoksista työelämän innovaatiotoiminnaksi - Työelämän kehittämisohjelma 2004-2010: arviointiraportti. Helsinki: Tekes. [in Finnish]

Oudhuis M. and Tengblad S. (2013) Experiences for Implementation of Lean Production: Standardization versus Self-Management: A Swedish Case Study. Nordic Journal of Working Life Studies 3 (1), 31-48.

(http://rossy.ruc.dk/ojs/index.php/njwls/article/view/2519/826, read 27 March 2013)

Perez C. (2002) Technological Revolutions and Financial Capital: The Dynamics of Bubbles and Golden Ages. Cheltenham: Edward Elgar.

Ramstad E. (2008) Innovation Generating Model - Simultaneous Development of Work Organization and Knowledge Infrastructure. TYKES Reports 65. Helsinki: Tekes.

Ramstad E. and Alasoini T. (2006) Interactive Research in Finland: Workplace Research from the 1940's to the Present Day. In Aagaard Nielsen K. and Svensson L. (eds.) Action and Interactive Research: Beyond Practice and Theory. Maastricht: Shaker Publishing, 158-169.

Schuler R. and Jackson S. (1987) Linking Competitive Strategies with Human Resources Management Practices. Academy of Management Executive 9(3), 207-219.

Seppälä P. and Klemola S. (2004) How Do Employees Perceive Their Organization and Job When Companies Adopt Principles of Lean Production? Human Factors and Ergonomics in Manufacturing 14 (2), 157-180.

Shipton H., Fay D., West M., Patterson M. and Birdi K. (2005) Managing People to Promote Innovation. Creativity and Innovation Management 14 (2), 118-128.

Totterdill P. with Exton O., Exton R. and Sherrin J. (2009) Workplace Innovation Policies in European Countries: A Report to KOWIN. Nottingham: UKWON.

Valeyre A., Lorenz E., Cartron D., Csizmadia P., Gollac M., Illéssy M. and Makó C. (2009) Working Conditions in the European Union: Work Organisation. Dublin: European Foundation for the Living and Working Conditions.

Veugelers R., Aiginger K., Breznitz D., Edquist C., Murray G., Ottaviano G., Hyytinen A., Kangasharju A., Ketokivi M., Luukkonen T., Maliranta M., Maula M., Okko P., Rouvinen P., Sotarauta M., Tanayama T., Toivanen O. and Ylä-Anttila P. (2009) Evaluation of the Finnish National Innovation System: Policy Report. Helsinki: Ministry of Education, Ministry of Employment and the Economy.

Womack J.P. and Jones D.T. (1996) Lean Thinking: Banish Waste and Create Wealth in Your Corporation. New York: Simon \& Schuster. 


\section{About the author}

Tuomo Alasoini

Chief Adviser at the Workplace Innovation and Development unit in Tekes - the Finnish Funding Agency for Innovation - and responsible Director of Tekes programme "Liideri Business, Productivity and Joy at Work" (2012-18). He completed his Doctoral thesis in Sociology in 1990 at the University of Helsinki and his has acted as Adjunct Professor at the University since 1995. From 1996 to 2010, he worked as Project Manager of the Finnish Workplace Development Programmes TYKE and TYKES.

E-mail: tuomo.alasoini@tekes.fi 